\title{
PERAN MEDIA SOSIAL DALAM STRATEGI KOMUNIKASI PEMASARAN DI SEBUAH PERGURUAN TINGGI SWASTA DI JAKARTA BARAT
}

\author{
Suhartono Chandra ${ }^{1}$, Richard Andrew ${ }^{2}$ \\ ${ }^{1}$ Jurusan Manajemen, Universitas Tarumanagara Jakarta \\ Email: suhartonochandra@fe.untar.ac.id \\ ${ }^{2}$ Jurusan Manajemen, Universitas Tarumanagara Jakarta \\ Email: richarda@fe.untar.ac.id
}

\begin{abstract}
At present time, in the digital age, the use of social media spreads faster than ever before. One common use of social media is in the application of marketing communication strategies. This strategy is usually used by institutions targeting Generation-Z, such as universities. The purpose of this study is to measure the level of optimization of the use of social media in a Private University in West Jakarta as one of the marketing communication strategies. The researcher used one method of data collection in qualitative research, namely in-depth interviews to 30 respondents from the academics in private universities who were the subjects of the study where 24 respondents were students and 6 were lecturers. The result of the study found that marketing communication strategy in higher education requires improvement because subpar performance is still present in the fields of management relations, news actualization, creativity, entertainment, consistency, customization, commitment, and attention. The result of the study revealed that the strategy will be optimal when news linearity is maintained, the amount of actual and creative content increases, reports on content are actualized, as well as making sure that links and citations for each content is made available.
\end{abstract}

Keywords: Marketing Communication, Social Media, Private University, Marketing Communication Strategies, Digital Marketing

\begin{abstract}
ABSTRAK
Dewasa ini, di era digital, penggunaan media sosial menyebar lebih cepat dari yang pernah terjadi sebelumnya. Salah satu penggunaan yang umum media sosial adalah dalam penerapan strategi komunikasi pemasaran. Strategi ini biasanya digunakan oleh institusi yang menargetkan Generasi-Z, seperti perguruan tinggi. Adapun tujuan dari penelitian ini adalah untuk mengukur tingkat optimalisasi penggunaan media sosial di salah satu Perguruan Tinggi Swasta di Jakarta Barat sebagai salah satu strategi komunikasi pemasaran. Peneliti menggunakan salah satu metode pengumpulan data dalam penelitian kualitatif, yaitu wawancara mendalam (in-depth interview) kepada 30 responden yang berasal dari sivitas akademika di perguruan tinggi swasta yang menjadi subyek penelitian dimana responden mahasiswa sebanyak 24 responden dan 6 responden dosen. Hasil penelitian menemukan bahwa strategi komunikasi pemasaran di perguruan tinggi tersebut masih perlu ditingkatkan karena ada yang belum optimal di bagian hubungan manajemen, aktualisasi berita, kreativitas, hiburan, konsistensi, kustomisasi, komitmen dan perhatian. Hasil penelitian mengungkapkan bahwa strategi tersebut akan lebih maksimal saat linearitas berita terjaga, jumlah konten yang aktual dan kreatif bertambah, laporan mengenai konten diaktualisasikan serta tautan dan kutipan pada setiap konten diupayakan eksistensinya.
\end{abstract}

Kata Kunci: Komunikasi Pemasaran, Media Sosial

\section{PENDAHULUAN}

\section{Latar Belakang}

Dalam beberapa tahun terakhir, peran media sosial di dunia berubah dengan sangat pesat. Bahkan Barenblatt (2015) menuturkan bahwa pengguna internet, khususnya yang berusia muda, memiliki lebih dari satu media sosial yang digunakan. James dan Levin (2015) menyatakan bahwa media sosial sudah menjadi hal yang tidak dapat dihilangkan dari dunia modern ini. Hal itu juga berlaku di Indonesia. Jika dahulu orang Indonesia akan merasa ada yang kurang saat tidak mempunyai telepon genggam maka sekarang orang muda Indonesia juga merasa ada yang kurang saat belum mempunyai media sosial pribadi 
terutama jika dikaitkan dengan dunia pergaulan di kota - kota besar. Mereka cenderung untuk berganti media sosial jika sudah banyak orang tua yang masuk ke zona nyaman mereka karena media sosial saat ini diidentifikasi sebagai sarana utama untuk aktualisasi diri dan oleh sebab itu terkadang seseorang dapat menghabiskan waktu yang cukup banyak di media sosial mereka saat ada waktu senggang. Dari media sosial orang - orang ini juga menemukan banyak hal yang berguna dalam kehidupan mereka mulai dari belanja kebutuhan sehari - hari, mencari teman lama yang sudah tidak berinteraksi dalam jangka waktu lama dan masih banyak lagi.

Ada banyak platform yang digunakan oleh orang Indonesia. Sepuluh di antaranya adalah Facebook, Twitter, Instagram, LinkedIn, Youtube, Whatsapp, Line, Skype, WeChat dan Blackberry Messenger. Sebagian orang di Indonesia bahkan memiliki dan rutin menggunakan kesepuluh platform tersebut secara bersamaan maka tidak heran waktu senggang pribadi akan habis dengan memperhatikan konten terbaru di masing - masing media sosial tersebut. Tidak hanya berhenti sampai kesepuluh platform tersebut, Indonesia juga memiliki beberapa platform hasil karya anak bangsa. Hal ini mencakup platform Buzzbuddies, Sebangsa, LiteBig, Catfiz, IMES Talk, Yogrt, Stealthchat, Oorth, Kwikku dan Inspirasi. Waktu senggang inilah yang kemudian dicoba untuk dimanfaatkan oleh beberapa institusi sebagai sarana komunikasi pemasaran mereka.

Ini jugalah yang dilakukan oleh perguruan tinggi swasta subyek penelitian, sebagai salah satu universitas swasta besar Indonesia yang berada di Jakarta Barat melalui pengembangan Divisi Website dan Media Sosial dalam Unit Khusus Hubungan Masyarakat sejak 2015. Namun, hal ini bukan berarti tanpa masalah. Terjadi pro dan kontra terhadap penggunaan media sosial oleh sebagian orang yang mengganggapnya tidak berguna dan cenderung untuk diremehkan keberadaannya terutama yang fanatik dan fokus dengan penggunaan media konvensional. Sedangkan sebagian besar perusahaan besar di dunia saja mulai berinvestasi secara khusus pada media sosial sebagai bagian dari komunikasi pemasaran mereka. Berdasarkan permasalahan tersebut, maka penelitian ini bertujuan untuk melihat secara lebih mendalam tentang peran media sosial dalam strategi komunikasi pemasaran di perguruan tinggi yang menjadi obyek penelitian. Adapun penelitian ini diharapkan dapat membuka wawasan dan meningkatkan kesadaran seluruh sivitas akademika, khususnya yang masih kontra terhadap penggunaan media sosial sehingga diharapkan di masa yang akan datang bagian yang menangani media sosial dapat menjadi suatu unit khusus dalam perguruan tinggi subyek penelitian.

\section{Landasan Teori}

Kusniadji (2017) menuturkan bahwa komunikasi pemasaran adalah kegiatan yang ditujukan untuk memperkenalkan, menjalin dan menciptakan interaksi antara organisasi dengan mitra dari organisasi tersebut. Adapun komunikasi pemasaran terpadu, yang juga dikenal dengan nama pemasaran hubungan, bekerja untuk berinteraksi secara spesifik dengan menggunakan pesan yang terarah melalui media yang mendetail pula (Blakeman, 2018). Dengan strategi yang baik, maka komunikasi pemasaran dapat meningkatkan preferensi merek dan pasar (Hossain et al, 2017). Kotler et al (2016) mengungkapkan bahwa komunikasi pemasaran terdiri dari beberapa kegiatan utama yakni iklan, promosi penjualan, publisitas, pemasaran langsung dan penjualan pribadi. Hampir seluruh bauran tersebut menggunakan teknologi pemasaran digital di era modern ini. 
Ryan (2016) menyebutkan ada beberapa elemen inti dalam pemasaran digital. Hal ini mencakup Website, Search Engine Optimizer (SEO), Pay per Click search Advertising (PPC), kerjasama digital, media massa digital, pemasaran via surat elektronik, Electronic Customer Relationship Management (E-CRM) dan tentu saja jaringan sosial melalui media sosial dalam bentuk yang sangat variatif. Media sosial itu sendiri menurut Larson dan Watson (2011) adalah suatu rangkaian aplikasi yang menghubungkan pelanggan dalam melakukan interaksi, penciptaan bersama, pertukaran informasi secara publik dan pembentukan jaringan komunitas. Hal ini selaras dengan perkembangan website yang tidak hanya diisi oleh seseorang saja tapi juga melibatkan semua pihak secara kolaboratif seperti yang diungkapkan oleh Kaplan dan Haenlein (2009). Secara umum media sosial juga dapat meningkatkan pola pikir dari konsumen dan nilai dari shareholder (Colicev et al, 2018) dan juga menstimulasi penjualan, penghematan biaya dan perluasan jumlah interaksi (Felix et al, 2016). Selain itu media sosial juga sangat penting untuk membangun sebuah merek dari suatu perusahaan terutama untuk tetap senantiasa menjaga relasi dengan sangat dekat kepada seluruh masyarakat terutama komunitas khusus dari merek tersebut seperti yang diutarakan oleh Habibi et al (2014).

Kesemua hal ini tentu saja dapat diaplikasikan tidak hanya pada industri yang berorientasi laba tetapi juga pada sektor nirlaba. Pada sektor nirlaba, Guo dan Saxton (2018) menyebutkan bahwa media sosial dapat digunakan untuk menarik perhatian apalagi jika organisasi nirlaba tersebut memiliki jaringan yang kuat, frekuensi yang sama dengan audiens dan mempunyai jumlah perbincangan yang cukup. Adapun salah satu sektor nirlaba yang dekat dengan kehidupan sehari - hari dunia akademik adalah perguruan tinggi. Dalam penelitian terdahulu yang dilakukan oleh Peruta et al (2017) tentang media sosial pada perguruan tinggi ditemukan bahwa jenis media sosial dan frekuensi dari konten yang dikeluarkan berkontribusi terhadap keeratan media sosial dengan sivitas akademika di dalam kampus maupun calon mahasiswa potensial di luar kampus.

Akan tetapi penelitian sebelumnya juga mengungkapkan bahwa penggunaan media sosial ini juga memiliki keterbatasan. Hal ini diungkapkan oleh Kimmons et al (2017) yang mengungkapkan penggunaan hanya seputar promosi kampus, bertujuan untuk membagi informasi, tautan ke kabar penting seputar kampus dan mengekspresikan sentimen positif atau netral terhadap sesuatu yang memiliki hubungan dengan kampus. Di Indonesia, Hastuti (2017) juga melakukan penelitian terhadap penggunaan media sosial khususnya Instagram. Dalam penelitian tersebut, Hastuti (2017) menyebutkan bahwa ada keterkaitan antara penggunaan media sosial tersebut dengan kepuasan, kepercayaan, dan keeratan. Oleh sebab itu dia memprediksi bahwa kepekaan, citra dan intensi untuk memilih tempat kuliah juga dapat ditingkatkan dengan penggunaan media sosial tersebut.

\section{METODE PENELITIAN}

Peneliti mengunakan salah satu metode pengumpulan data dalam penelitian kualitatif, yaitu wawancara mendalam (in-depth interview) kepada 30 responden yang terdiri atas 24 responden mahasiswa dan 6 responden dosen. Hayati (2015) menyebutkan bahwa metode kualitatif sering disebut sebagai metode naturalistik karena penelitian dilakukan pada kondisi alamiah dan mempelajari tentang manusia. Lebih lanjut Tohirin (2012) mengungkapkan bahwa penelitian kualitatif bermaksud untuk memahami fenomena subjek pada suatu konteks khusus. 
Adapun subyek dari riset ini adalah sivitas akademika salah satu Perguruan Tinggi Swasta di Jakarta Barat. Salah satu alasan dari pemilihan subyek ini adalah kemudahan untuk mengambil sampel karena latar belakang dari peneliti. Responden yang diwawancara berasal dari periode pengambilan yang sama agar hasil dari wawancara tidak menjadi bias karena adanya improvisasi dari tim media sosial kampus. Kedua jenis responden diwawancarai untuk mengetahui seberapa jauh penggunaan media sosial dan integrasi komunikasi dengan perguruan tinggi tempat mereka berada dari perspektif mereka. Hal ini juga mencakup persepsi mereka terhadap hubungan manajemen, aktualisasi berita, kreativitas dan hiburan dalam setiap pesan yang mereka lihat. Setelah itu jawaban seluruh sampel yang diambil digabungkan untuk memeriksa konsistensi, kustomisasi, komitmen dan perhatian mereka terhadap media sosial yang dijalankan oleh Perguruan Tinggi Swasta subyek penelitian. Peneliti berharap dari hasil penelitian ini perguruan tinggi swasta tersebut dapat merencanakan dan menerapkan strategi media sosial yang lebih baik sebagai bagian yang penting dalam komunikasi pemasaran terintegrasi.

Berikut ini adalah tabel yang menunjukkan variasi poin yang ditanyakan dalam wawancara yang dilakukan oleh peneliti:

Tabel 1. Poin dalam Wawancara

\begin{tabular}{|c|c|l|}
\hline Nomor & Topik & \multicolumn{1}{c|}{ Materi yang Diajukan } \\
\hline 1 & Hubungan manajemen & $\begin{array}{l}\text { Linearitas media sosial universitas dengan fakultas dan lembaga } \\
- \text { lembaga dalam universitas. }\end{array}$ \\
\hline 2 & Aktualisasi berita & $\begin{array}{l}\text { Kuantitas dari berita yang ditayangkan dan kecepatan tayang } \\
\text { berita dengan peristiwa yang terjadi. }\end{array}$ \\
\hline 3 & Kreativitas & $\begin{array}{l}\text { Improvisasi yang dilakukan dalam setiap konten media sosial } \\
\text { termasuk tautan yang digunakan. }\end{array}$ \\
\hline 4 & Hiburan & $\begin{array}{l}\text { Jumlah konten yang menghibur dan kualitas dari konten yang } \\
\text { menghibur tersebut. }\end{array}$ \\
\hline 5 & Konsistensi & $\begin{array}{l}\text { Jeda waktu antara konten yang dikirim dengan konten }- \text { konten } \\
\text { berikutnya dalam media sosial. }\end{array}$ \\
\hline 7 & Kustomisasi & $\begin{array}{l}\text { Variasi konten dan tautan yang dikirim dalam media sosial } \\
\text { dalam suatu periode yang sama. }\end{array}$ \\
\hline 8 & Komitmen & $\begin{array}{l}\text { Jumlah berita yang ditayangkan berbanding dengan jumlah } \\
\text { peristiwa yang terjadi seputar kampus. }\end{array}$ \\
\hline Perhatian & $\begin{array}{l}\text { Jumlah kutipan langsung pernyataan dalam setiap konten media } \\
\text { sosial dari narasumber. }\end{array}$ \\
\hline
\end{tabular}

\section{HASIL DAN PEMBAHASAN}

Berdasarkan hasil wawancara yang sudah dirangkum oleh peneliti maka didapatkan beberapa temuan sebagai berikut:

a. Hubungan manajemen

Ada beberapa berita yang diwartakan pada media sosial fakultas tetapi belum diberitakan pada tingkat universitas. Sebaliknya ada beberapa berita yang diwartakan di tingkat universitas tetapi tidak terekspos sama sekali sehingga tidak diketahui di tingkat fakultas. Hal ini terkadang dikarenakan kekurangtahuan sivitas akademika dalam menjalankan proses yang cukup panjang terkait prosedur layak tayang.

b. Aktualisasi berita

Jumlah berita pada beberapa fakultas cenderung sangat sedikit dan kurang informatif sehingga tidak membantu dalam proses pemasaran dari program studi yang ada di fakultas tersebut. Selain itu berita yang tayang kadang sudah tidak aktual karena 
jarak antara tayang dan peristiwa berita itu berselang terlalu lama. Hal ini terjadi terutama karena proses translasi yang tidak menjadi kesatuan dari berita tersebut.

c. Kreativitas

Improvisasi yang dilakukan pada setiap konten yang dibuat oleh tim media sosial universitas, terutama untuk berita yang terkait dengan pengumuman, bentuknya masih sesuai dengan gaya desain standar universitas sehingga kurang mendukung peningkatan kesadaran pihak eksternal terhadap universitas tersebut.

d. Hiburan

Saat ini jumlah konten yang bersifat hiburan cenderung terus berkurang. Padahal konten yang menghibur di tengah maraknya berita yang diwartakan dapat meningkatkan interaksi dengan para pengguna media sosial. Selain itu ketidakadaan hiburan yang bersifat positif juga mengurangi kemungkinan untuk meningkatkan pergerakan ke dalam setiap konten yang dipublikasikan pada media sosial kampus.

e. Konsistensi

Konsistensi konten yang dipublikasikan cenderung mengalami penurunan karena fluktuasi yang cukup tinggi dari pemberitaan yang dilakukan terhadap peristiwa peristiwa yang terjadi di universitas. Terkadang volume konten, terutama yang bersifat berita, sangat padat dan banyak di suatu minggu akan tetapi di minggu yang lain cenderung menghilang.

f. Kustomisasi

Variasi tautan pada setiap konten masih dapat ditingkatkan karena tidak semua konten memiliki tautan informasi yang cukup singkat, jelas dan padat. Adapun yang dapat dipertimbangkan adalah kemungkinan untuk membuat setiap konten memiliki tautan dengan website utama dari universitas yang disertai dengan kemungkinan tautan jika kampus memiliki media partner untuk berita - berita utama.

g. Komitmen

Perlunya komitmen bersama di setiap lini dalam kampus karena masih saja ada egosentris di beberapa tingkatan yang berbeda sehingga berita tidak sampai secara cepat dan akurat sampai ke level terendah ataupun tertinggi dengan cepat. Hal ini terlihat karena pemberitaan cenderung masih jauh lebih sedikit jika dibandingkan dengan peristiwa yang terjadi kecuali pada fakultas tertentu.

h. Perhatian

Jumlah kutipan langsung yang menjadi bukti selain foto kehadiran dari tim peliput pada setiap berita menjadi elemen yang penting dalam cuplikan tulisan di setiap konten media sosial perguruan tinggi. Selain itu kutipan yang baik dan tepat sasaran dapat mengedukasi para pengguna media sosial kampus.

Berdasarkan temuan - temuan tersebut maka penulis menyarankan beberapa strategi komunikasi pemasaran untuk mengatasi permasalahan pada media sosial universitas yang diteliti sebagai berikut:

a. Memastikan linearitas berita dari fakultas dan lembaga - lembaga dalam kampus.

Staf di tingkat fakultas dan lembaga - lembaga dalam kampus perlu rajin untuk mengaktualisasi berita sendiri dan juga memeriksa berita yang ditayangkan pada tingkat universitas. Sebaliknya pihak universitas juga perlu rajin untuk mengaktualisasi berita sendiri dan memeriksa berita yang ditayangkan pada tingkat fakultas dan lembaga - lembaga dalam kampus untuk memunculkan linearitas berita.

b. Meningkatkan jumlah berita yang diwartakan pada media sosial kampus.

Jumlah berita yang ditayangkan pada media sosial sebaiknya berjumlah cukup banyak dan minimal terdapat satu konten berita yang ditayangkan pada satu hari di 
tingkat fakultas dan lembaga - lembaga dalam kampus. Hal ini akan membuat jumlah berita di tingkat universitas akan lebih banyak dan berkualitas sehingga sivitas akademika ataupun calon sivitas akademika akan mampu menemukan konten dengan mudah.

c. Meningkatkan kecepatan tayang berita yang diwartakan pada media sosial kampus.

Staf media sosial di tingkat fakultas dan lembaga - lembaga maupun di tingkat pusat perlu proaktif dalam mendapatkan berita yang terbaru agar berita dapat segera ditayangkan dalam minggu yang sama dengan terjadinya peristiwa. Perlu dipikirkan untuk mengurangi kendala administratif dan pengesahan dari aktualisasi berita yang terkadang disebabkan karena kekurangtahuan sivitas akademika.

d. Menambah improvisasi konten sehingga lebih menghibur dengan kreatif.

Konten yang ada pada media sosial akan lebih baik jika memiliki unsur hiburan. Misalnya pada berita mengenai acara seminar mungkin diselingi dengan cuplikan momen menghibur yang dapat dilihat dari ekspresi peserta ataupun pembicara. Selain itu, konten menghibur juga bisa dihadirkan pada saat jumlah berita pada media sosial berkurang karena memasuki masa liburan panjang perkuliahan.

e. Membuat buku laporan secara periodik untuk memantau berita yang diwartakan.

Setiap konten baik yang belum maupun yang sudah berhasil ditayangkan harus dilaporkan secara periodik. Laporan ini harus dilaporkan minimal satu bulan sekali sehingga setiap laporan dapat diverifikasi kebenarannya. Selain untuk verifikasi, laporan ini juga berguna saat terjadi revisi dari konten yang sudah tayang maupun belum tayang sehingga pihak yang diberitakan dapat membantu mengawasi.

f. Menambah tautan pada setiap konten yang dibuat dengan media partner.

Setiap konten yang dibuat sebaiknya dihubungkan dengan media partner yang ada. Misalnya saat suatu kampus memiliki kerjasama dengan suatu media partner dan media tersebut menayangkan berita terkait acara yang dimaksud maka berita tersebut sebaiknya ditautkan dalam media sosial sehingga menambah jumlah pembaca dari kedua konten secara bersamaan.

g. Memastikan jumlah peristiwa positif yang terjadi diberitakan secara massal.

Setiap kali ada prestasi yang berhasil diraih, baik oleh karyawan, dosen maupun mahasiswa sebaiknya diberitakan secara massal di media sosial tingkat fakultas dan lembaga - lembaga maupun universitas. Apabila prestasi tersebut tingkat nasional dan internasional maka sebaiknya diberitakan juga di media publik baik secara konvensional maupun secara elektronik.

h. Meningkatkan jumlah kutipan langsung dalam setiap konten berita.

Setiap berita sebaiknya memiliki kutipan langsung yang dapat digunakan sebagai salah satu kata - kata inspiratif oleh tokoh utama dalam berita yang ditayangkan dalam media sosial tersebut. Hal ini lebih dapat diperkuat terutama pada media sosial yang memiliki fleksibilitas jumlah kata yang relatif tinggi.

\section{KESIMPULAN DAN SARAN}

Berdasarkan penelitian yang dilaksanakan oleh peneliti maka dapat disimpulkan bahwa media sosial di Perguruan Tinggi Swasta yang diteliti sudah cukup baik dan akan lebih maksimal jika linearitas berita terjaga, jumlah konten yang aktual dan kreatif ditambah, laporan mengenai konten diaktualisasikan serta tautan dan kutipan pada setiap konten diupayakan eksistensinya. Adapun saran - saran bagi peneliti lanjutan terkait hal ini adalah adanya studi banding mengenai jumlah konten yang ada di setiap fakultas dan lembaga - lembaga yang ada jika saling diperbandingkan dan juga jika dibandingkan 
dengan institusi yang memiliki kapabilitas lebih tinggi baik secara nasional maupun internasional.

\section{Ucapan Terima kasih}

Peneliti berterima kasih kepada semua pihak yang tidak dapat disebutkan satu per satu di Perguruan Tinggi Swasta subyek penelitian yang telah membantu kelancaran proses penelitian ini.

\section{REFERENSI}

Barenblatt, C. (2015). "Marketing to millennials". available at: www.bizcommunity.com/Article/196/347/123834.html\#more (accessed July 14, 2018).

Blakeman, R. (2018). Integrated marketing communication: creative strategy from idea to implementation. Rowman \& Littlefield, Lanham, Maryland.

Colicev, A., Malshe, A., Pauwels, K., \& O'Connor, P. (2018). Improving consumer mindset metrics and shareholder value through social media: the different roles of owned and earned media". Journal of Marketing, 82(1), 37-56.

Felix, R., Rauschnabel, P. A., \& Hinsch, C. (2017). Elements of strategic social media marketing: A holistic framework. Journal of Business Research, 70, 118-126.

Guo, C., \& Saxton, G. D. (2018). Speaking and being heard: how nonprofit advocacy organizations gain attention on social media. Nonprofit and Voluntary Sector Quarterly, 47(1), 5-26.

Habibi, M. R., Laroche, M., \& Richard, M. O. (2014). The roles of brand community and community engagement in building brand trust on social media. Computers in Human Behavior, 37, 152-161.

Hastuti, A. P. (2017). Analisis Pengaruh Media Sosial Instagram Terhadap Pembentukan Brand Attachment (Studi: Universitas Muhammadiyah Surakarta) (Doctoral dissertation, Universitas Muhammadiyah Surakarta).

Hayati, N. (2015). Pemilihan metode yang tepat dalam penelitian: metode kuantitatif dan metode kualitatif". Jurnal Tarbiyah Al-Awlad, 4(1), 345-357.

Hossain, M., Kabir, S., \& Rezvi, R. I. (2017). Influence of the integrated marketing communication on brand orientation and market orientation: a literature review. Australian Journal of Business Science Design \& Literature, 10(1).

James, A. and Levin, J. (2015), "Digital natives: A portrait of tech and urban youth", Sunday Times Generation Next 2015, May, p. 16.

Kaplan, A. M., \& Haenlein, M. (2010). Users of the world, unite! The challenges and opportunities of Social Media. Business Horizons, 53(1), 59-68.

Kimmons, R., Veletsianos, G., \& Woodward, S. (2017). Institutional uses of Twitter in US higher education. Innovative Higher Education, 42(2), 97-111.

Kotler, P., Keller, K. L., Brady, M., Goodman, M., \& Hansen, T. (2016). Marketing Management,: Pearson Education Limited, Harlow.

Kusniadji, S. (2017). Strategi Komunikasi Pemasaran dalam Kegiatan Pemasaran Produk Consumer Goods: Studi kasus Pada PT Expand Berlian Mulia Di Semarang. Jurnal Komunikasi, 8(1), 83-98.

Larson, K., \& Watson, R. (2011). "The value of social media: toward measuring social media strategies". Thirty second international conference on information system, Shanghai, 2011. 
Peruta, A., \& Shields, A. B. (2017). Social media in higher education: understanding how colleges and universities use Facebook. Journal of Marketing for Higher Education, 27(1), 131-143.

Ryan, D. (2016). Understanding digital marketing: marketing strategies for engaging the digital generation. Kogan Page Limited, New York.

Sugiyono. (2002). Metode Penelitian Administrasi. Penerbit Alfabeta, Bandung.

Tohirin. (2012). Metode Penelitian Kualitatif dalam Pendidikan dan Bimbingan Konseling: Pendekatan Praktis untuk Peneliti Pemula dan Dilengkapi dengan Contoh Transkrip Hasil Wawancara serta Model Penyajian Data. Rajawali Pers, Jakarta. 